\title{
The Little Ice Age: evidence from a sediment record in Gullmar Fjord, Swedish west coast
}

\author{
I. Polovodova Asteman ${ }^{1}$, K. Nordberg ${ }^{1}$, and H. L. Filipsson ${ }^{2}$ \\ ${ }^{1}$ Department of Earth Sciences, University of Gothenburg, PO Box 460, 40530 Gothenburg, Sweden \\ ${ }^{2}$ Department of Geology, Lund University, Sölvegatan 12, 22362 Lund, Sweden
}

Correspondence to: I. Polovodova Asteman (irina.polovodova@gvc.gu.se)

Received: 28 August 2012 - Published in Biogeosciences Discuss.: 15 October 2012

Revised: 25 January 2013 - Accepted: 7 February 2013 - Published: 1 March 2013

\begin{abstract}
We discuss the climatic and environmental changes during the last millennium in NE Europe based on a ca. 8-m long high-resolved and well-dated marine sediment record from the deepest basin of Gullmar Fjord (SW Sweden). According to the ${ }^{210} \mathrm{~Pb}$ - and ${ }^{14} \mathrm{C}$-datings, the record includes the period of the late Holocene characterised by anomalously cold summers and well-known as the Little Ice Age (LIA). Using benthic foraminiferal stratigraphy, lithology, bulk sediment geochemistry and stable carbon isotopes we reconstruct various phases of the cold period, identify its timing in the study area and discuss the land-sea interactions occurring during that time. The onset of the LIA is indicated by an increase in cold-water foraminiferal species Adercotryma glomerata at $\sim 1350 \mathrm{AD}$ The first phase of the LIA was characterised by a stormy climate and higher productivity, which is indicated by a foraminiferal unit of Nonionella iridea and Cassidulina laevigata. Maximum abundances of $N$. iridea probably mirror a short and abrupt warming event at $\sim 1600 \mathrm{AD}$. It is likely that due to land use changes in the second part of the LIA there was an increased input of terrestrial organic matter to the fjord, which is indicated by lighter $\delta^{13} \mathrm{C}$ values and an increase of detritivorous and omnivorous species such as Textularia earlandi and Eggerelloides scaber. The climate deterioration during the climax of the LIA (1675-1704 AD), as suggested by the increase of agglutinated species, presence of Hyalinea balth$i c a$, and a decline of $N$. iridea may have driven the decline in primary productivity during this time period.
\end{abstract}

\section{Introduction}

A number of proxy-based reconstructions show that over the last millennium several intervals with anomalously cold summers were characteristic of the period, well-known as the Little Ice Age or LIA (among others: Hughes and Diaz, 1994; Fricke et al., 1995; Bianchi and McCave, 1999; McDermott et al., 2001; Nordli, 2001; Xoplaki et al., 2005; Lund et al., 2006; Leijonhufvud et al., 2010; Trouet et al., 2009; review in Ljungqvist, 2009, 2010; Cage and Austin, 2010, Sicre et al., 2011). The LIA was associated with a widespread expansion and subsequent fluctuation of glaciers in the Arctic and alpine regions at lower latitudes, which happened in response to climatic changes at $\sim 1300-1850 \mathrm{AD}$ (Porter, 1986; Miller et al., 2012). This climatic deterioration coincided with reduced solar activity (Mauquoy et al., 2002), regular decline in summer insolation as Earth moved steadily farther from the Sun during the Northern Hemisphere summer (Wanner et al., 2011), increased volcanism (Miller et al., 2012) and weakening of the North Atlantic Oscillation after its strongly positive state during the Medieval Warm Period (Trouet et al., 2009). Some studies also associated the cooling with a decreased volume transport of the Gulf Stream (Lund et al., 2006).

There is growing evidence that the Little Ice Age occurred throughout the Northern Hemisphere (Ljungqvist, $2009,2010)$ and is distinctly seen as taking place during the last three to four centuries with a termination at $\sim 1900 \mathrm{AD}$ (Grove, 2001). Other studies, however, mention that the LIA started somewhere between $\sim 1300$ and $1400 \mathrm{AD}$ (Fricke et al., 1995; Mauquoy et al., 2002; Moberg et al., 2005; Cage and Austin, 2010; Ljungqvist, 2010; Miller et al., 2012). 
The period 1675-1710 AD has been identified as the coldest phase (climax) of the LIA (Lamb, 1983), which was preceded by an abrupt and rather short-lived warming around $1600 \mathrm{AD}$, according to some studies (Cage and Austin, 2010; Hass et al., 2010). The Little Ice Age has been generally regarded as a stormy period (Lamb, 1983; de Jong et al., 2007, 2009). Hass (1996) divided the LIA into three parts: intervals 1350-1550 and 1750-1900 AD, characterised by a stormy mode of sedimentation, and an interval 1550-1750 AD, characterised by a "calmer" sediment deposition in the Skagerrak. Using two raised bogs in a near-coastal part of SW Sweden, Björck and Clemmensen (2004) also reported an increased aeolian sediment influx (ASI) caused by winter storminess at 1810-1820, 1650 and 1450-1550 AD. Also, according to some studies (Clarke and Rendell, 2009; Clemmensen et al., 2009), the climax of the LIA coincided with sand movement and dune formation in Denmark.

High-resolution fjord sediment records produce archives, which contain information about variations in marine, terrestrial and atmospheric environments (Howe et al., 2010) and therefore allow for the study of air-ocean-land interactions in great detail. The Skagerrak region with its fjords is a key area for investigation of such complex interactions: it acts as a main depositional basin for the North Sea; it is highly influenced by the North Atlantic Oscillation, a dominant pattern of atmospheric circulation over the North Atlantic, and it has been classified as a coastal area with a high cumulative human impact (Halpern et al., 2008). From the few marine records containing the Little Ice Age in the Skagerrak and attempting to link the air-ocean or land-sea interactions, the greatest interest in terms of highresolution LIA stratigraphy represent studies of Hass (1996, 1997), Brückner and Mackensen (2006) and Erbs-Hansen et al. (2011) (Fig. 1). Some of the previous studies, however, included ${ }^{14} \mathrm{C}$ dates obtained from mixed benthic foraminiferal faunas and therefore potentially contain some chronological bias. This paper presents the first well-dated and highlyresolved foraminiferal stratigraphy of the Little Ice Age from the sedimentary archives of the Scandinavian coast. With a higher resolution compared to other studies, this investigation has the potential to reconstruct short-term environmental and climatic fluctuations during the LIA and contribute to a better understanding of Northern European climate over the last millennium. Using lithology, bulk sediment geochemistry, benthic foraminifera and carbon stable isotopes we intend to reconstruct the various phases of this cold period; to identify its timing (onset, climax and termination) in the study area and to correlate our marine data with terrestrial records.

\section{Study area}

Gullmar Fjord is one of several silled fjords situated in the middle part of the Bohuslän province on the Swedish west coast (Fig. 1a, b). It is among the most well-studied fjords in the world. Over the last ca. $40 \mathrm{yr}$, many studies were performed in the fjord regarding its hydrography (e.g. Rydberg, 1977; Björk and Nordberg, 2003; Arneborg, 2004; Arneborg et al., 2004; Erlandsson et al., 2006) and primary productivity (Lindahl and Hernroth, 1983; Schöllhorn and Graneli, 1996; Lindahl et al., 1998; Belgrano et al., 1999). Due to negligible tidal activity and high sedimentation rates $\left(0.7-1.4 \mathrm{~cm} \mathrm{a}^{-1}\right.$ : Filipsson and Nordberg, 2004a) Gullmar Fjord is a highresolution environmental archive acting as a large sedimentary trap (Filipsson and Nordberg, 2010). This resulted in numerous investigations into sedimentary records from the fjord basin, including pollen, dinoflagellate cysts and benthic foraminifera as proxies of environmental changes during the Holocene and recent past (Fries, 1951; Qvale et al., 1984; Nordberg et al., 2000, 2009; Godhe et al., 2001; Gustafsson and Nordberg, 2001; Godhe and McQuoid, 2003; Filipsson et al., 2004; Filipsson and Nordberg, 2004a, b, 2010; Harland et al., 2006; Risgaard-Petersen et al., 2006; Polovodova et al., 2011).

The Gullmar fjord has a sill area at a depth of $42 \mathrm{~m}$ and a maximum basin depth of $120 \mathrm{~m}$. The water masses are stratified with respect to salinity and density into four layers (Fig. 1c). At the surface a first thin layer $(<1 \mathrm{~m})$ of river water from Örekilsälven occurs, which does not significantly influence the hydrography of the fjord (Arneborg, 2004). The residence times for the second and third layers are 20-38 days and 29-60 days, respectively (Arneborg, 2004), whereas the deepest layer has a residence time of approximately one year (Nordberg et al., 2000; Erlandsson et al., 2006). The long residence time of the deep water and high oxygen consumption rates in the fjord provide a likelihood of hypoxia $\left(<2 \mathrm{~mL} \mathrm{O}_{2} \mathrm{~L}^{-1}\right)$ in the basin (Inall and Gillibrand, 2010). Indeed, during the 20th century oxygen consumption in the fjord increased from $0.21 \mathrm{~mL} \mathrm{O}_{2} \mathrm{~L}^{-1}$ month $^{-1}$ (1950-1970) to about $0.35 \mathrm{~mL} \mathrm{O}_{2} \mathrm{~L}^{-1} \mathrm{month}^{-1}$ (1970s and the early 1980s) and to about $0.41 \mathrm{~mL} \mathrm{O}_{2} \mathrm{~L}^{-1}$ month $^{-1}$ from 1989 onward (Erlandsson et al., 2006). Given that concentration of dissolved oxygen during a bottom water renewal usually ranges between $\sim 4$ and $8 \mathrm{~mL} \mathrm{O}_{2} \mathrm{~L}^{-1}$ (Filipsson and Nordberg, 2004a), and the residence time of bottom water is $1 \mathrm{yr}$, the annual consumption rates may remove all of the oxygen before the next successive bottom water renewal. Starting in 1973, however, the timing of the basin water renewal in Gullmar Fjord occurs approximately 20 days later compared to the period prior to 1973 , which is a suggested result of climate variations triggered by North Atlantic Oscillation (NAO) (Erlandsson et al., 2006). Therefore, annual stagnation periods and temporary hypoxic events, characteristic features in Gullmar Fjord, became significantly stronger during the second part of the 20th century (Filipsson and Nordberg, 2004; Nordberg et al., 2009 and references therein) and were likely less frequent/severe during the Medieval Warm Period (Polovodova et al., 2011). 


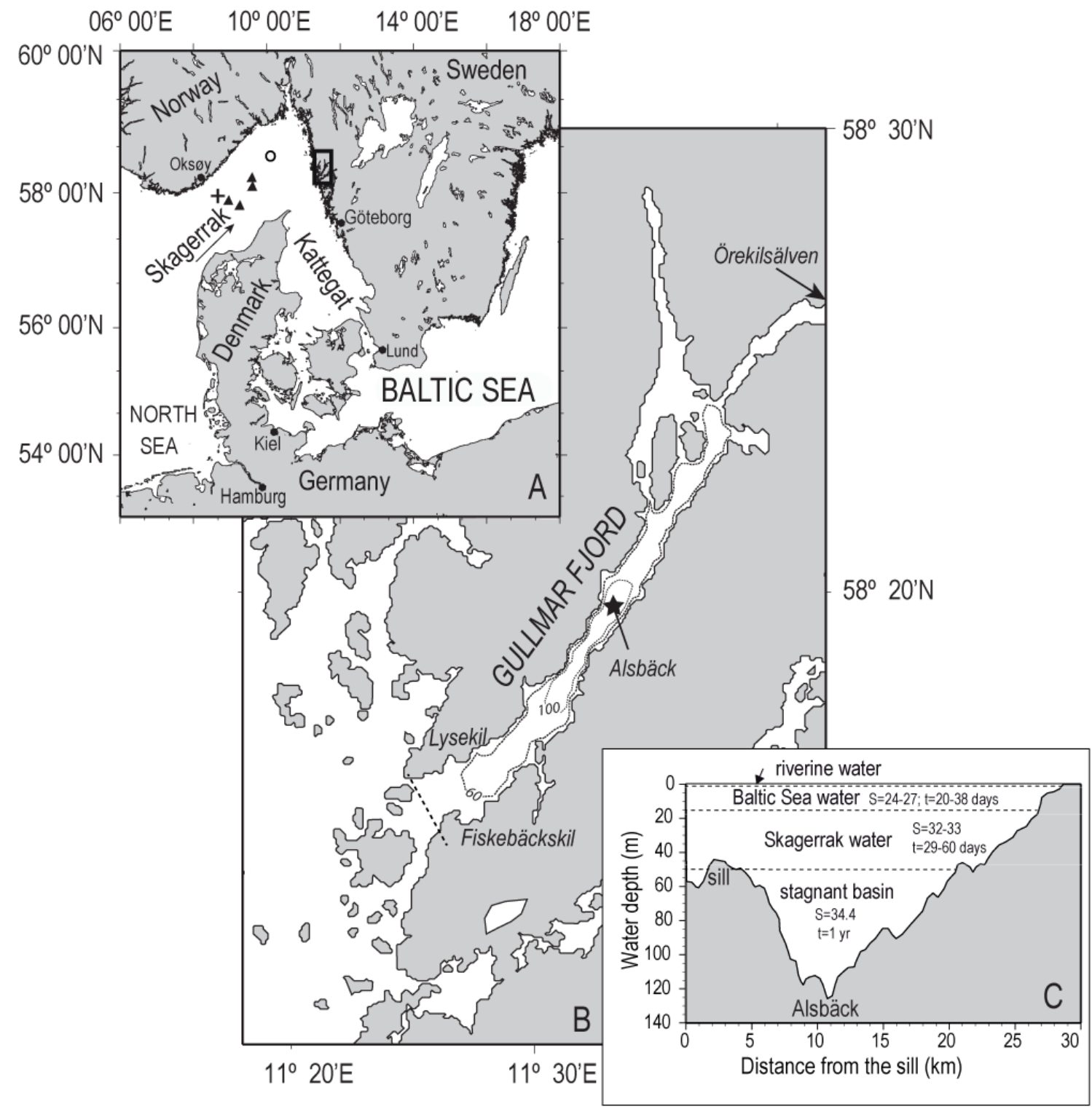

Fig. 1. Overview map of the study area. (A) A rectangle shows the location of Gullmar Fjord in the Skagerrak area; the positions of sedimentary archives used by previous studies are indicated as a circle and a plus for cores studied by Erbs-Hansen et al. (2011) and Brückner and Mackensen (2006), correspondingly, whereas black triangles are sediment cores studied by Hass (1997). (B) Overview of the Gullmar Fjord area; a star in the deepest basin (Alsbäck) indicates sampling site for cores GA113-2Aa, 9004 and GA113-091; a dashed line in the outer fjord indicates location of the sill. (C) Overview of water masses in the longitudinal profile of the Gullmar Fjord with indication of salinity $(S)$ and residence times $(t)$ typical for each water layer (Arneborg, 2004).

\section{Methods}

This study is based on three sediment cores: GA113-2Aa, 9004 and G113-091, which were all collected at 116-m water depth in Gullmar Fjord (58 $\left.17.57^{\prime} \mathrm{N}, 11^{\circ} 23.06^{\prime} \mathrm{E}\right)$ (Fig. 1). The cores 9004 (731-cm-long) and G113-091 (195-cm-long) were sampled with a piston corer $(\varnothing=7.6 \mathrm{~cm})$ during expeditions of the R/V Svanic and R/V Skagerrak in 1990 and 2009 , respectively. The core GA113-2Aa (60-cm-long) was taken with a Gemini corer $(\varnothing=8 \mathrm{~cm})$ aboard R/V Skagerrak in 1999. Together cores GA113-2Aa and 9004 represent a nearly complete sediment record with a small gap in-between due to difficulties with the piston corer methodology in relatively soft sediments. In order to determine the size of the gap, core G113-091 was used.

In the laboratory, all cores were split in two halves. One half was saved for dinoflagellate cyst analysis (for the cores G113-091 \& 9004 - to be presented elsewhere; for core GA113-2A see Harland et al., 2006). The other half was used for foraminiferal and geochemical studies. Twelve mollusc 
shells were found in life position in cores G113-091 and 9004 and were subjected to radiometric ${ }^{14} \mathrm{C}$ AMS dating. The shells were dated at the Ångström laboratory (Uppsala University, Sweden) using the marine model calibration curve (Reimer et al., 2004; Bronk Ramsey, 2005). The half-life used is $5568 \mathrm{yr}$, and the margin of error is $1 \sigma$. Ages are normalized to $\delta^{13} \mathrm{C}$ of $-25 \%$ according to Stuiver and Polach (1977), and a correction corresponding to $\delta^{13} \mathrm{C}=0 \%$ (not measured) versus PDB has been applied. The radiocarbon dates were corrected using a reservoir age of $500 \mathrm{yr}(\Delta R=100)$ (Nordberg and Possnert, unpublished data; see detailed discussion in Polovodova et al., 2011). For dating of core GA113-2Aa and details regarding the ${ }^{210} \mathrm{~Pb}$ dating method, see Filipsson and Nordberg (2004a) and Nordberg et al. (2001), respectively.

Prior to foraminiferal studies, core 9004 was sliced into 1$\mathrm{cm}$ intervals down to a depth of $28 \mathrm{~cm}$ and thereafter into 2-cm intervals. Core G113-091 was cut into 1-cm slices until $19 \mathrm{~cm}$, and thereafter $2-\mathrm{cm}$ slices were taken. The same preparation technique was used for all samples: they were weighed, freeze-dried and the water content was determined. The measurements of organic carbon $\left(\mathrm{C}_{\text {org }}\right)$ in the bulk sediment and stable carbon isotopes on tests of benthic foraminifer Cassidulina laevigata were performed on cores GA113-2Aa and 9004. All organic carbon samples from core GA113-2Aa were analysed at University of Gothenburg (Sweden) using a Carlo Erba NA $1500 \mathrm{CHN}$ analyser. Samples from core 9004 were run at Bremen University (Germany) using a Vario EL III CHN analyser and simultaneously were subject to the total nitrogen (TN) measurements. In core G113-091 we measured $\delta^{13} \mathrm{C}$ on tests of $C$. laevigata and conducted a benthic foraminiferal analysis in order to determine the gap between the cores GA113-2Aa and 9004. All $\delta^{13} \mathrm{C}$ measurements were run at the Department of Geosciences, University of Bremen, using a Finnigan Mat 251 mass spectrometer equipped with an automatic carbonate preparation device.

All foraminiferal samples were washed over $63 \mu \mathrm{m}$ and 1$\mathrm{mm}$ sieves and treated with sodium diphosphate $\left(\mathrm{Na}_{4} \mathrm{P}_{2} \mathrm{O}_{7}\right)$, when necessary, in order to disintegrate sediment aggregates. To estimate the sand content, the size fractions $>63 \mu \mathrm{m}$ were dried at $50^{\circ} \mathrm{C}$ and weighed. The foraminifera-rich samples were split and at least 300 specimens were counted in each sample from the dried $>63 \mu \mathrm{m}$ fraction. In total, 262 samples were analysed for foraminiferal fauna, 72 samples of them are reported here. Both relative (\%) and absolute abundances (ind. $\mathrm{g}^{-1}$ dry sed.) for the benthic species were determined. In order to distinguish the foraminiferal units with different species dominance we performed a simple CABFAC factor analysis with Varimax rotation using the software PAST, University of Oslo (Hammer et al., 2001). The analysis included all species with relative abundances $\geq 5 \%$ in at least one sample.

Results of $\mathrm{C}_{\text {org }}$ and $\delta^{13} \mathrm{C}$ measurements from the cores GA113-2Aa \& 9004 are given in Filipsson and Nordberg

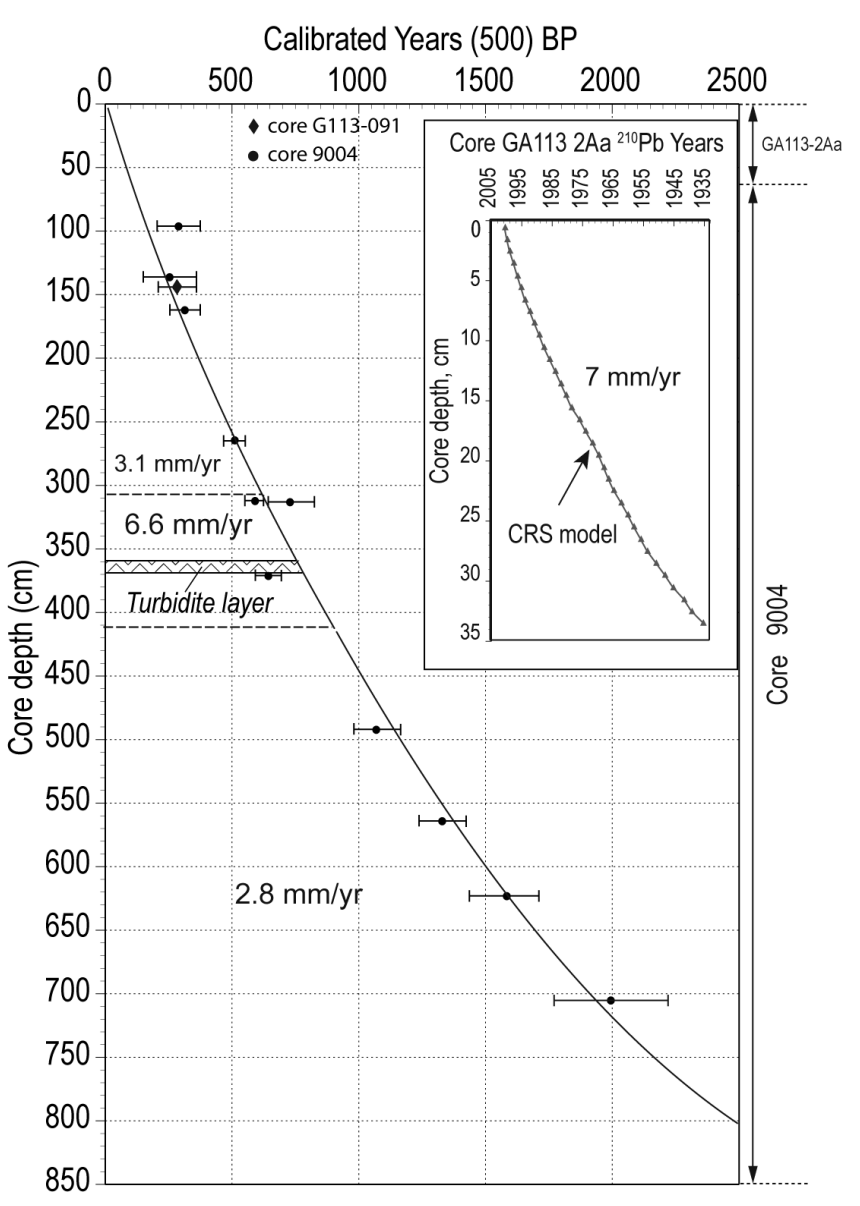

Fig. 2. Age model based on ${ }^{210} \mathrm{~Pb}$ (core GA113-2Aa; Filipsson and Nordberg, 2004a) and ${ }^{14} \mathrm{C}$ AMS datings (core 9004; Filipsson and Nordberg, 2010). The new ${ }^{14} \mathrm{C}$ AMS dating for the core G113-091 is indicated by a diamond. In the revised version of ${ }^{14} \mathrm{C}$ age model (Polovodova et al., 2011) a 500-yr reservoir correction has been applied, whereas a rectangle with a zigzag pattern at $357-371 \mathrm{~cm}$ indicates the primary position of a turbidite, which was removed from the age curve. Separated by dashed lines are curve intervals, characterised by changes in a sedimentation rate.

(2004, 2010). For the results on benthic foraminifera and dinoflagellate cysts analyses from the core GA113-2Aa see Filipsson and Nordberg (2004) and Harland et al. (2006), respectively. The part of the benthic foraminiferal record covering the Medieval Warm Period (core 9004: 350-500 cm) was previously published in Polovodova et al. (2011). In the current study we focus on the last $1000 \mathrm{yr}$ of the high-resolution record with a special emphasis on the Little Ice Age.

\subsection{Results}

\subsection{Chronology}

The records GA113-2Aa \& 9004 span from approximately 350 BC to 1999 AD (Table 1, Fig. 2), and include the Roman Warm Period (RWP), the Viking Age/Medieval Warm 
Table 1. Radiocarbon dating results based on 12 double mollusc shells recovered intact from the cores 9004 and G113-091. The correction of ${ }^{14} \mathrm{C}$ ages for reservoir age is modified after Filipsson and Nordberg (2010) and a $500 \mathrm{yr}$ reservoir age has been used based on a complementary mollusc shell dating (Nordberg and Possnert, unpublished data; Polovodova et al., 2011). The genuine depths of core 9004 in the second column were corrected for $+60 \mathrm{~cm}$ in order to include the core GA113-2Aa on top of the record.

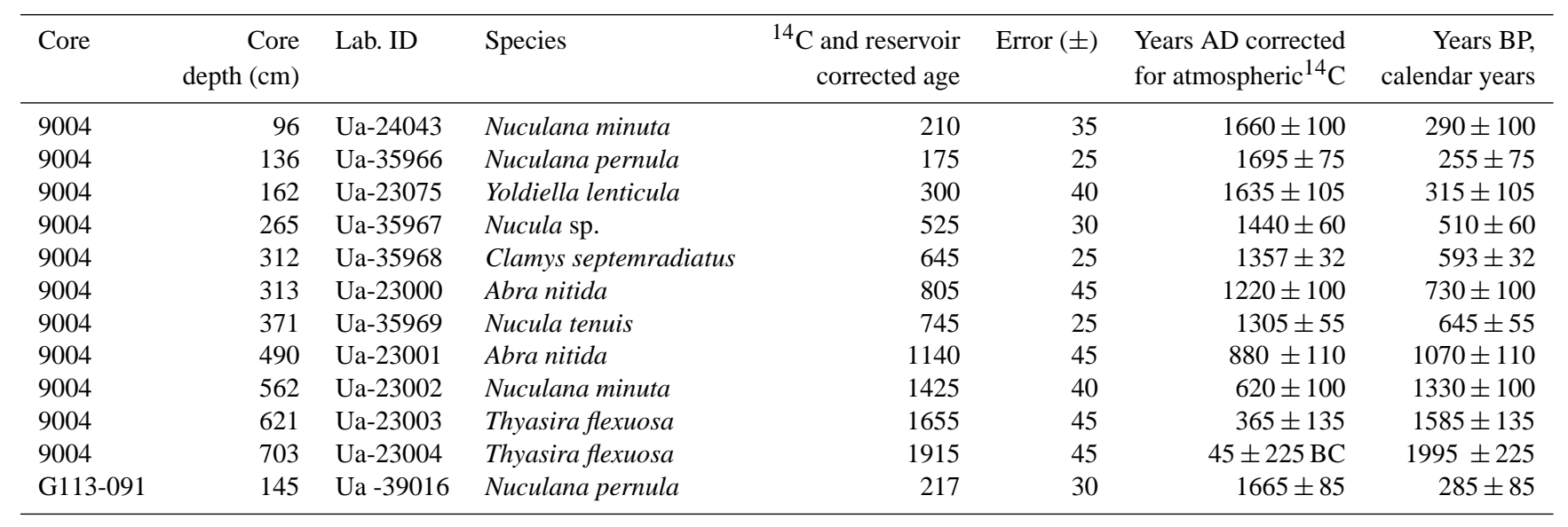

Period (MWP), the Little Ice Age (LIA) and the recent warming of the 1900s (Filipsson and Nordberg, 2010). For the chronologies of cores GA113-2Aa and 9004 based on ${ }^{210} \mathrm{~Pb}$ (Fig. 2) and ${ }^{14} \mathrm{C}$ AMS datings, see Filipsson and Nordberg (2004a, 2010). The age model for core 9004 was revised by Polovodova et al. (2011) and the updated version is used in this study (Fig. 2, Table 1). For core G113-091 the only intact mollusc shell of Nuculana pernula yields an age of $1665 \pm 85 \mathrm{AD}$ (Table 1; Fig. 2), which indicates that this core represents the time interval from the middle part of the Little Ice Age to 2009.

\subsection{Organic geochemistry of bulk sediment}

The organic carbon $\left(\mathrm{C}_{\text {org }}\right)$ data for sediment cores GA113-2Aa and 9004 (Figs. 4-5) are discussed in detail by Filipsson and Nordberg (2010). The C/N ratio measurements are only available for core 9004 and therefore $\mathrm{C} / \mathrm{N}$ data for the last $100 \mathrm{yr}$ are missing. In core $9004 \mathrm{C} / \mathrm{N}$ ratio ranges from 5 to 10 , indicating organic matter of primarily marine origin (C/N ratio of 5-7; Redfield et al., 1963). The long-term average of the ratio is 8.3 . Around $170-\mathrm{cm}$ depth (ca. $1650 \mathrm{AD}$ ) a slight offset occurs in the $\mathrm{C} / \mathrm{N}$ values, which divides the Little Ice Age into two periods: (1) before $1650 \mathrm{AD}$ with $\mathrm{C} / \mathrm{N}$ values higher than the long-term average and (2) after $1650 \mathrm{AD}$ with $\mathrm{C} / \mathrm{N}$ ratio below the average. Around $1900 \mathrm{AD}$, the $\mathrm{C} / \mathrm{N}$ ratio increases again and reaches 9.5 on top of the record $(\sim 1900 \mathrm{AD})$.

\subsection{Lithology}

\subsubsection{Core GA113-2Aa}

The sediment column in general was olive-green-grey and contained mainly organic-rich silt and clay. The sediment surface was light brown, which indicated oxic conditions. An increased amount $(9 \%)$ of sand-sized fraction $(>63 \mu \mathrm{m})$ was found between 51 and $43 \mathrm{~cm}(\sim 1915 \mathrm{AD})$. For a more detailed lithology of a Gemini core GA113-2Aa see Filipsson and Nordberg (2004a).

\subsubsection{Core 9004}

The distribution of sand-sized fraction $(>63 \mu \mathrm{m})$ and lithology of the core 9004 were previously discussed in Filipsson and Nordberg (2010) and Polovodova et al. (2011). Based on the presence of exotic foraminiferal species (>50\% of a shallow water species Elphidium excavatum) a distinct light grey horizon of clay and silt at $367-364 \mathrm{~cm}$ was interpreted as a turbidite (Polovodova et al., 2011; Fig. 4a). Within depth interval $350-60 \mathrm{~cm}$, which corresponds to the Little Ice Age (1350-1900 AD), the sand-sized fraction indicated three distinct units (Figs. 4-5). A first coarser unit at ca. 1350-1600 AD (350-190 cm) can be identified based upon high variability of the sand fraction. A second unit between AD 1600 and $1850(190-100 \mathrm{~cm})$ was characterized by less variability and finer sediment. A third unit at ca. $1850-1900$ AD $(100-60 \mathrm{~cm})$ was also characterised by coarser sediment.

\subsubsection{Core G113-091}

In general, the sediment column consisted of dark-olive-grey mud (gyttja clay) with mottled (containing black dots) sections in places. However, there were some distinct changes in colour within the interval $185-129 \mathrm{~cm}$. At $185-181 \mathrm{~cm}$ the generally dark-grey mud contained horizontal layers of darker sediment, which gradually faded away at $174 \mathrm{~cm}$. An interval of a light-grey mud was encountered at a depth of $174-171 \mathrm{~cm}$ and had a distinctly lighter 5-6 mm-thick 


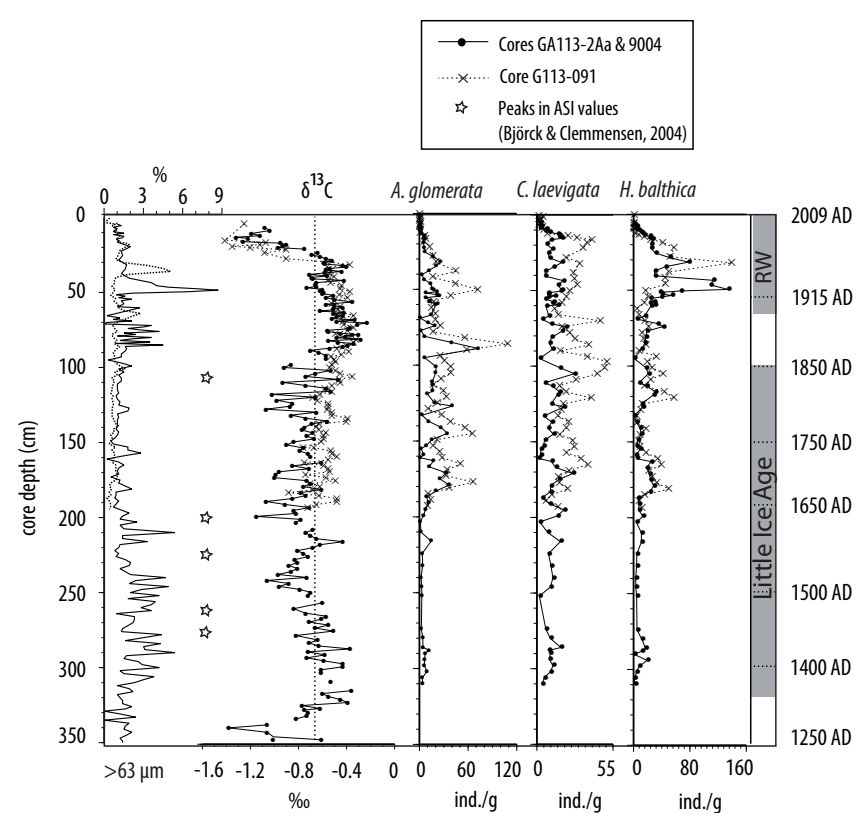

Fig. 3. The $\delta^{13} \mathrm{C}(\% \circ)$ and foraminiferal (ind. $\mathrm{g}^{-1}$ ) correlations between cores GA113-2Aa, 9004 and G113-091. The abbreviation RW indicates the recent warming of the 1900s. The dates (yr) for time intervals on the right hand side are from Filipsson and Nordberg (2004a) and Polovodova et al. (2011). The isotopic data for GA113-2Aa \& 9004 are given after Filipsson and Nordberg (2010).

horizon in the middle. After the light-grey layer, the sediments became dark-grey again until $152 \mathrm{~cm}$. Another light grey horizon was found at $152-129 \mathrm{~cm}$, thereafter the sediment had continuously a dark-grey colour. The surface of the core G113-091 was oxidised and had a light-brown colour down to $5 \mathrm{~cm}$. The sand-sized fraction displayed two distinct maxima (5 and $3 \%$ ) at depths of 36 and $64 \mathrm{~cm}$ and had a long-term average of $0.9 \%$ (Fig. 3).

\subsection{Stable carbon isotopes}

\subsubsection{Cores GA113-2Aa \& 9004: $\delta^{13} \mathrm{C}$ record of the LIA (1350-1900 AD)}

The full record of $\delta^{13} \mathrm{C}$ values from the cores GA113-2Aa and 9004 covering the last ca. two millennia was discussed in detail by Filipsson and Nordberg (2010). In the current paper we concentrate on the part relevant to the Little Ice Age.

The average $\delta^{13} \mathrm{C}$ value for the GA113-2Aa-9004 record was $-0.65 \%$. The $\delta^{13} \mathrm{C}$ record of the LIA around $310-\mathrm{cm}$ sediment depth (ca. $1350 \mathrm{AD}$ ) began with less negative values as compared to the long-term average (Fig. 3) and the heavier values persisted until ca. $210 \mathrm{~cm}(1500 \mathrm{AD})$. After that $\delta^{13} \mathrm{C}$ values reached their minimum of $-1.15 \%$ and had a distinctly more negative phase, which lasted until almost 100-cm depth (ca. 1850 AD). Afterwards, the trend of the $\delta^{13} \mathrm{C}$ record changed again towards the less negative values,
Table 2. The factors resulted from a CABFAC factor analysis with varimax rotation performed on foraminiferal counting data for species contributing by $>5 \%$ to the assemblages in at least one sample.

\begin{tabular}{crr}
\hline Factors & Eigenvalue & Variance $(\%)$ \\
\hline 1 & 125.29 & 62.02 \\
2 & 28.985 & 14.35 \\
3 & 14.338 & 7.1 \\
4 & 10.389 & 5.14 \\
\hline
\end{tabular}

reached a maximum of $-0.2 \%$ and remained less negative until the termination of the LIA.

\subsubsection{Core G113-091}

The stable carbon isotope record for G113-091 showed a fairly good correlation with the $\delta^{13} \mathrm{C}$ record derived from GA113-2Aa \& 9004 down to a depth of ca. $90 \mathrm{~cm}$ (Fig. 3). Below $90 \mathrm{~cm}$ the G113-091 curve had a slight displacement of $0.2-0.4 \%$ o from the GA113-2Aa \& 9004 record. Nevertheless, the good correlation of both isotopic records until $90 \mathrm{~cm}$ indicated that there is no gap between the cores GA113-2Aa and 9004 . This was also confirmed by analysis of the dominant foraminiferal species in both records (Fig. 3). Therefore, the depths of the core 9004 had to be corrected for $-40 \mathrm{~cm}$, as compared to those presented in Filipsson and Nordberg (2010) and Polovodova et al. (2011), which both used " $+100 \mathrm{~cm}$ " depth correction in order to compensate for a gap between two cores. This literally means that a $60-\mathrm{cm}$ long GA113-2Aa core could be directly placed on top of the core 9004.

\subsection{Foraminifera}

\subsubsection{The last millennium: ca. 900-2001 AD}

For foraminiferal data from the GA113-2Aa \& 9004 record, we performed a factor analysis, which resulted in 4 factors, explaining as much as $89 \%$ of variance (Table 2, Fig. 4). According to Klovan and Imbrie (1971), the minimum absolute factor value is a zero, which indicates that the variable contributes nothing to the factor. In our study eight foraminiferal species had high (>1.0) absolute values of factor scores (Table 3, Fig. 4), which resulted in four foraminiferal assemblage units. Each foraminiferal unit was named after the most important species explaining each factor. Thus, Factor 1 (62\% of variance) corresponded to the Nonionella irideaCassidulina laevigata unit. Factor 2, which corresponded to Stainforthia fusiformis unit, accounted for $14 \%$ of variance and also included species Textularia earlandi, Bolivina pseudopunctata and Bulimina marginata. Factors 3 and 4 accounted for 7 and $5 \%$ of variance and corresponded to units of Adercotryma glomerata and Hyalinea balthica, 

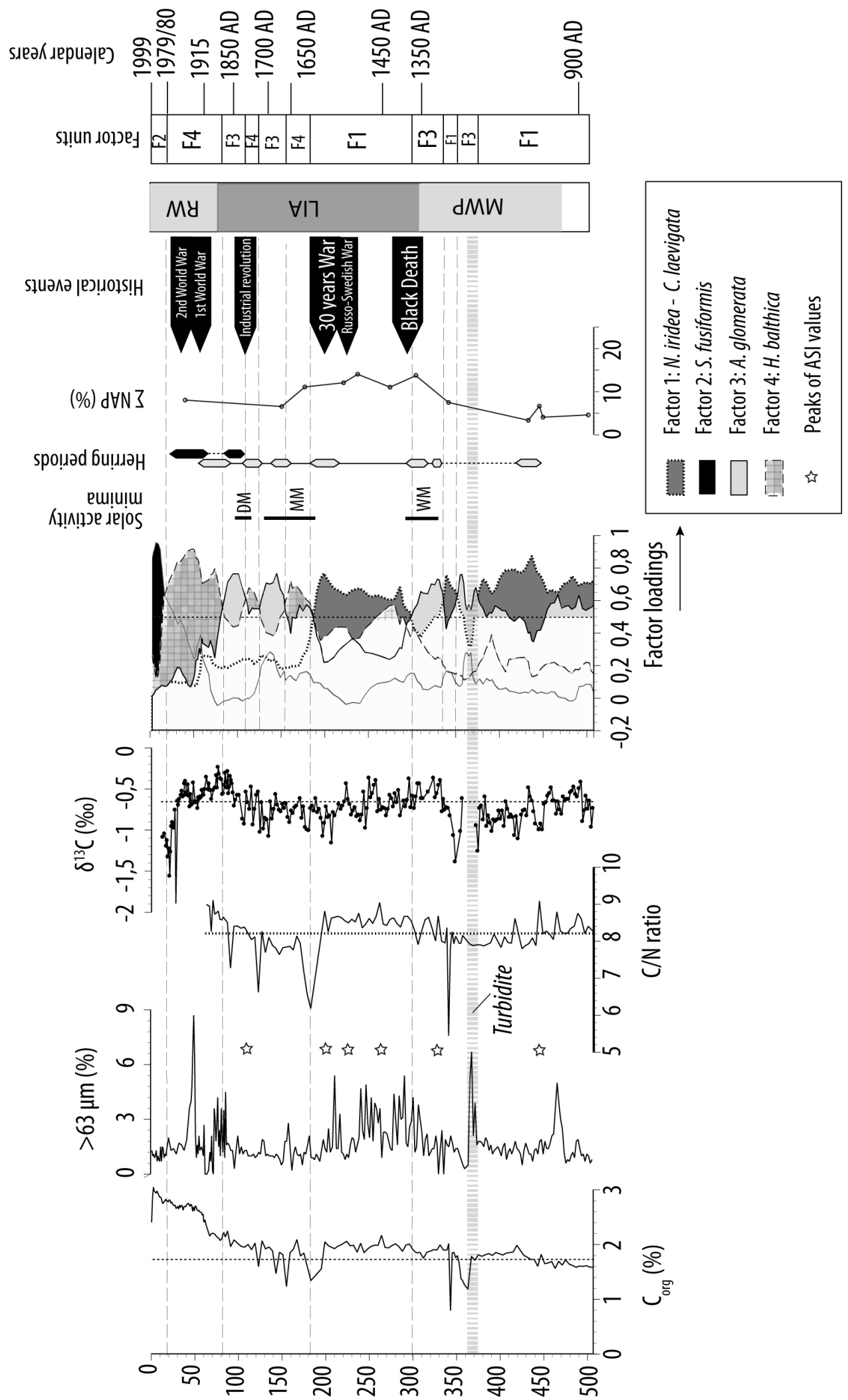

(u) प1dәр әر0)

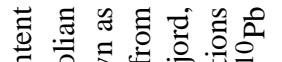

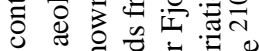

च 娄

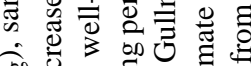

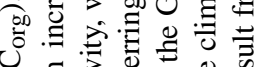

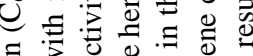

ป

चี

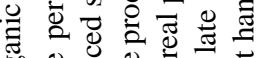

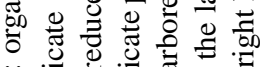

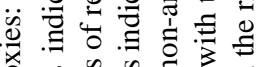

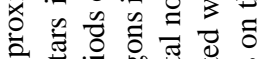

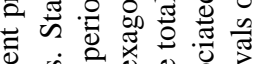

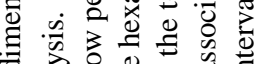

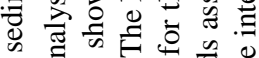

का चै

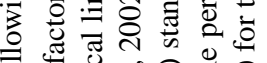

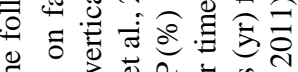

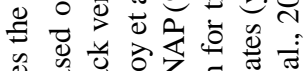

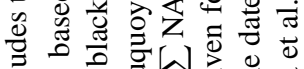

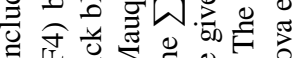

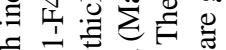

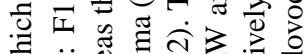

उ

ष̛⿱

के

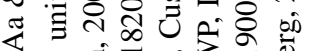

ส $\overline{0}$

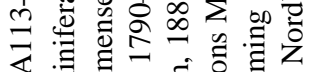

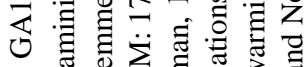

현

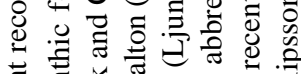

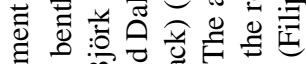

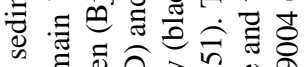

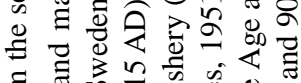

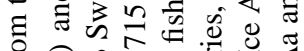

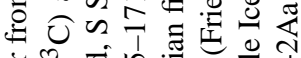

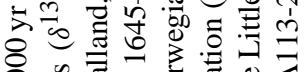

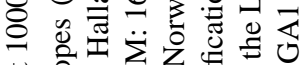

丞

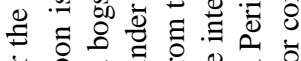

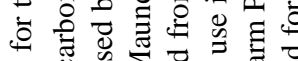

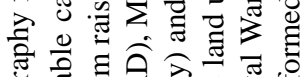

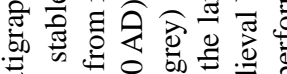

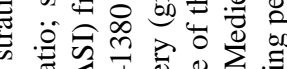

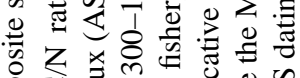

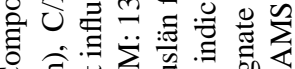

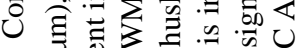

+่

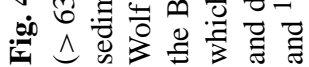




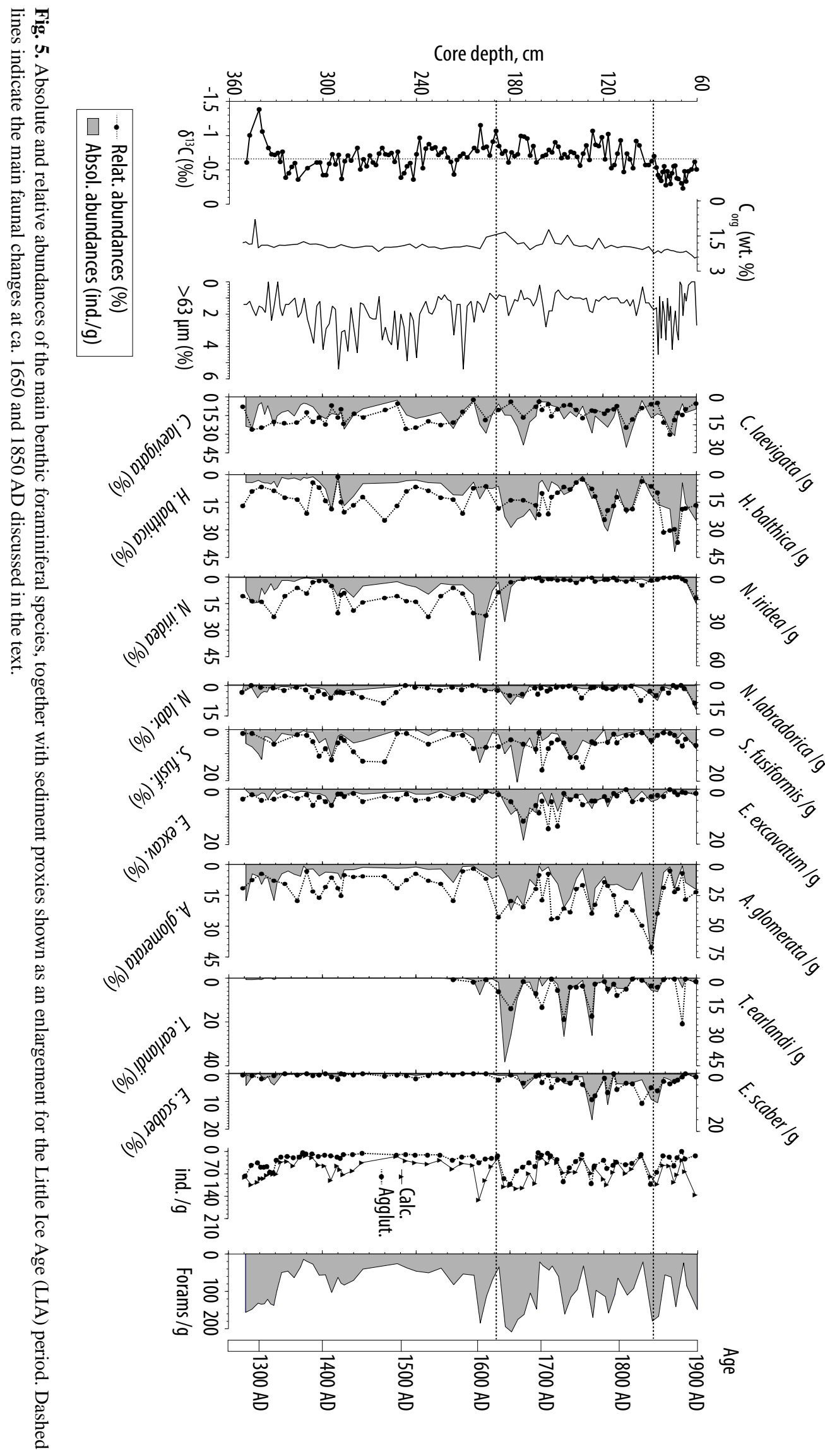


respectively. The fourth unit also included species $C$. laevigata and T. earlandi. The " $N$. iridea-C. laevigata" unit dominated the record at 500-375 $\mathrm{cm}(\sim 900-1150 \mathrm{AD})$ and $300-170 \mathrm{~cm}$ depth $(\sim 1350-1650$ AD) (Fig. 4). The Adercotryma glomerata unit interrupted its dominance at $335 \mathrm{~cm}$ $(\sim 1300 \mathrm{AD})$. From $\sim 1650$ to $1900 \mathrm{AD}$ the record alternated between foraminiferal units 3 and 4 (A. glomerata versus H. balthica). After $1900 \mathrm{AD}$ (70 cm depth), however, Hyalinea balthica unit dominated for ca. $80 \mathrm{yr}$ and was replaced by unit 2 represented by $S$. fusiformis as the main species.

\subsubsection{The Little Ice Age: 1350-1900 AD}

In general, species composition of the benthic foraminiferal fauna during the Little Ice Age was characterized by three dominant (> 10\%) species: A. glomerata, C. laevigata and H. balthica, whereas Eggerelloides scaber, Elphidium excavatum, N. iridea, S. fusiformis, Reophax subfusiformis and T. earlandi were present as accessory species $(<10 \%)$. Also, Nonionella iridea was a co-dominant species (20-30\%) during the first part of the Little Ice Age (ca. 1300-1650 AD).

Altogether 156 benthic foraminiferal species were found in the part of the record corresponding to the Little Ice Age. Among them 42 species had agglutinated tests and 114 species were calcareous. The Fisher $\alpha$-diversity (Murray, 2006) varied between 6 and 20, with a mean of 13 (not shown). The average absolute foraminiferal abundance was 87 ind. $\mathrm{g}^{-1}$ of dry sediment, (14-208 ind. $\mathrm{g}^{-1}$ ). The highest absolute abundance of foraminifera was encountered at $179 \mathrm{~cm}$ depth (ca. 1650 AD: see Fig. 5).

The absolute abundances (ind. $\mathrm{g}^{-1}$ ) displayed rather lower values over the time period from ca. 1450 to $1600 \mathrm{AD}$ (Fig. 5). At the same time, there was a clear increase of the foraminifer $N$. iridea, which reached its highest abundances ( $30 \%$ and 56 ind. $\mathrm{g}^{-1}$ ) during the LIA at $\sim 1600 \mathrm{AD}$.

In general, calcareous foraminiferal species dominated for the majority of the LIA. However during the second part of the LIA, agglutinated species such as A. glomerata, E. scaber and T. earlandi became important components of the foraminiferal assemblages (Fig. 5). Both relative and absolute abundances demonstrated a salient faunal change at $180 \mathrm{~cm}$ (ca. $1650 \mathrm{AD}$ ) when $N$. iridea became rare in the record. Around the same time A. glomerata, E. excavatum, E. scaber, S. fusiformis and T. earlandi all increased. The foraminiferal absolute abundances showed high values from 1650 to 1850 A.D with two minima at ca. 1630 and $1700 \mathrm{AD}$.

Hyalinea balthica became a prominent species in the record between $\sim 1650$ and $1700 \mathrm{AD}$ (Figs. 4, 5), but thereafter experienced several short declines until $1850 \mathrm{AD}$, after which its absolute abundance increased again. After $1850 \mathrm{AD}$ there was also a significant increase in a portion of calcareous species, whereas some agglutinated and calcareous species, such as A. glomerata, C. laevigata, E. excavatum and $E$. scaber declined during that time.
Table 3. The varimax scores for factors $1-4$. The bold numbers indicate foraminiferal species with high $(>1)$ absolute values of factor scores.

\begin{tabular}{lrrrr}
\hline Foram. species & Factor 1 & Factor 2 & Factor 3 & Factor 4 \\
\hline A.glomerata & -0.10768 & -0.070154 & $\mathbf{5 . 3 3 8 1}$ & 0.016301 \\
A. planus & 0.055213 & 0.021256 & 0.011319 & -0.030299 \\
B.pseudopunct. & -0.11202 & $\mathbf{1 . 8 7 7 7}$ & -0.05062 & 0.35149 \\
B. marginata & 0.34813 & $\mathbf{1 . 4 7 8}$ & -0.4567 & 0.92736 \\
C.laevigata & $\mathbf{2 . 3 8 3 9}$ & -0.88175 & 0.97848 & $\mathbf{1 . 7 6 3 7}$ \\
C. reniforme & 0.0077358 & 0.44531 & 0.066155 & 0.099771 \\
Cribrost. sp. & 0.038509 & 0.025065 & 0.27017 & -0.089008 \\
C. lobatulus & 0.29699 & 0.088751 & 0.20022 & 0.11073 \\
C. nitida & 0.060098 & 0.028202 & 0.11089 & -0.041738 \\
E. scaber & -0.26005 & 0.064873 & 0.61528 & 0.246 \\
E.excavatum & -0.082485 & 0.45029 & 0.42016 & 0.64108 \\
E.incertum & -0.011122 & 0.20031 & -0.067762 & 0.12595 \\
Elph. sp. & 0.1241 & 0.061917 & -0.010176 & 0.006397 \\
G. auriculata & 0.076751 & -0.025578 & -0.059181 & 0.031602 \\
G. turgida & 0.025327 & 0.077637 & 0.09994 & 0.25327 \\
H. baltica & 0.14513 & -0.47949 & -0.49283 & $\mathbf{4 . 9 0 0 4}$ \\
L. goesi & 0.13924 & -0.16283 & 0.69875 & 0.076081 \\
I. islandica & 0.021199 & -0.0138 & 0.0056691 & 0.024997 \\
I. norcrossi & 0.17626 & -0.095165 & -0.062956 & 0.17307 \\
M. barleean. & 0.46682 & -0.089688 & -0.022884 & 0.023435 \\
M. subrot. & 0.13755 & -0.071081 & 0.06433 & 0.1651 \\
N. labrad. & 0.20474 & 0.41638 & 0.14557 & 0.54104 \\
N. iridea & $\mathbf{4 . 9 0 5}$ & 0.23259 & -0.45699 & -0.87469 \\
P. osloensis & -0.058897 & 0.10956 & 0.161 & 0.27298 \\
P. williams. & 0.2882 & 0.021939 & 0.13268 & 0.0015362 \\
Q. seminula & 0.4742 & -0.093081 & 0.18083 & 0.15535 \\
Recurv. sp. & 0.0027056 & -0.01394 & 0.013286 & 0.0082206 \\
R. subfusif. & 0.65934 & -0.2133 & 0.50517 & 0.082465 \\
S. fusiformis & 0.49417 & $\mathbf{4 . 4 9 0 2}$ & 0.33699 & -0.30734 \\
T. tricarinata & 0.41554 & 0.03763 & 0.34257 & -0.21743 \\
T. earlandi & -0.63152 & $\mathbf{2 . 0 7 5}$ & 0.10634 & $\mathbf{1 . 3 9 1 7}$ \\
V. media & 0.082701 & 0.0097254 & 0.29911 & -0.021164 \\
\hline & & & & \\
& & & & \\
& & &
\end{tabular}

\subsection{Discussion}

\subsection{Benthic foraminiferal record of the Little Ice Age}

\subsubsection{0-1650 AD}

During ca. 1350-1650 AD we observed increased scores of Factor 1 represented by $N$. iridea and $C$. laevigata (Fig. 4). This agrees with previous studies based on benthic foraminiferal stratigraphy from the Skagerrak (Hass, 1997; Erbs-Hansen et al., 2011), which report high abundances of C. laevigata after $1450 \mathrm{AD}$ and suggest increased storminess, enhanced mixing of the water column and more fresh phytodetritus reaching the sea floor. Those studies, however, do not report any increase in $N$. iridea, which is probably due to an analysis of the $100-$ and $125-\mu \mathrm{m}$ sediment fractions for benthic foraminifera. A short and abrupt climate warming occurred at $1540-1610 \mathrm{AD}$ as it is suggested by the benthic foraminiferal $\delta^{18} \mathrm{O}$ record from the Scottish fjords (Cage and Austin, 2010). We speculated that Nonionella iridea is a species indicative of fresh phytodetritus pulses occurring during the Medieval Warm Period in Gullmar Fjord (Polovodova et al., 2011). It is a cosmopolitan 
Table 4. The ecological preferences of Nonionella iridea summarised for different settings. The information given in remarks indicates either parameters reported as essential for higher abundances of $N$. iridea, or refers to microhabitat preferences of this species.

\begin{tabular}{|c|c|c|c|c|c|}
\hline $\begin{array}{l}\text { Geographical } \\
\text { setting }\end{array}$ & $\begin{array}{r}\text { Water depth } \\
(\mathrm{m})\end{array}$ & $\begin{array}{r}\text { Temperature } \\
\left({ }^{\circ} \mathrm{C}\right)\end{array}$ & $\begin{array}{r}\text { Salinity } \\
(\mathrm{psu})\end{array}$ & Remarks & Reference \\
\hline Gulf of Cadiz & $40-95$ & - & - & Muddy sediment; low water energy & Mendes et al. (2004) \\
\hline $\begin{array}{l}\text { Rhône prodelta } \\
\text { (NW Mediterranean) }\end{array}$ & 67 & 16.3 & - & $\begin{array}{l}\text { High labile organic matter } \\
\text { (spring bloom) }\end{array}$ & Goineau et al. (2012) \\
\hline Bay of Biscay & 130 & $10.8-11.3$ & $35.3-35.4$ & Spring bloom & Duchemin et al. (2007) \\
\hline $\begin{array}{l}\text { Hebridean shelf } \\
\text { (off W Scotland) }\end{array}$ & $167-218$ & $7.5-10$ & $34.5-35.25$ & Infaunal & Murray (2003) \\
\hline \multirow[t]{2}{*}{ Skagerrak } & $>450$ & $6-6.5$ & $>35$ & - & Alve and Murray (1995) \\
\hline & 320 & - & - & Fresh phytodetritus & Alve (2010) \\
\hline \multirow[t]{2}{*}{$\begin{array}{l}\text { North Atlantic } \\
\text { (deep sea) }\end{array}$} & $>1900$ & $3.4-3.7$ & $34.4-34.9$ & $\begin{array}{l}\text { Spring bloom; } \\
\text { embedded in mud cysts }\end{array}$ & Gooday and Hughes (2002) \\
\hline & $1100 ; 1926$ & $3.4-3.7$ & 34.9 & Shallow infaunal & Hughes et al. (2000) \\
\hline
\end{tabular}

species, which occurs within a broad bathymetric range and has slightly different temperature preferences depending on a shelf or a deep-sea habitat (Table 4 ). The temperature tolerance of $N$. iridea within the Northern Europe and at depth ranges similar to deep Gullmar Fjord (Table 4) indicates that the species usually occurs at temperatures higher than $5.7^{\circ} \mathrm{C}$ (a long-term temperature average for the deep water in the fjord; SMHI, 2012). In paleostudies, Nonionella iridea is found in higher abundances in Eemian interglacial deposits (Seidenkrantz, 1993; Seidenkrantz and Knudsen, 1994) and Schröder-Adams (1991) reports it as a typical Holocene species. Therefore, it appears rather likely that $N$. iridea responded positively to both the warming event (at ca. $1600 \mathrm{AD}$ ) and the increase of phytodetritus, and therefore may be considered as a proxy of climate warming during the LIA. Nonionella iridea disappeared from the record after $1650 \mathrm{AD}$, which coincides with the Maunder Minimum in solar activity between 1645-1715 AD (Mauquoy et al., 2002) and the climax of the LIA (1675-1710 AD; Lamb, 1983). This period would likely be characterised by a shorter growing season of phytoplankton and therefore by less food available for fresh-phytodetritus feeders like $N$. iridea. Indeed, according to a tree ring-based climate reconstruction from west-central Sweden, the LIA was characterised by colder summer conditions during 1600-1900 AD, whereas milder summers prevailed during 1350-1600 AD (Gunnarson et al., 2011).

\subsubsection{0-1900 AD}

From Fig. 4, it emerges that the part of our record corresponding to ca. 1650-1900 AD represents a consecutive alternation of factors 3 and 4 (A. glomerata and $H$. balthica units), which implies variable environmental conditions during this time period. Below we discuss both the A. glomerata and $H$. balthica units and speculate about possible environmental changes associated with them.

\subsubsection{Adercotryma glomerata: a proxy of climate deterioration}

Using the $\delta^{18} \mathrm{O}$ of benthic foraminifera, Brückner and Mackensen (2006) suggest enhanced circulation and warmer temperatures from ca. 1630 to $1870 \mathrm{AD}$. The latter is contradictory to our results, which clearly show three repeated increases of the A. glomerata unit corresponding well with periods of reduced solar activity (Fig. 4): the Wolf (1300-1380 AD), the Maunder (1645-1715 AD) and the Dalton (1790-1820 AD) minima (Eddy, 1976; Mauquoy et al., 2002). Reduced solar activity has long been considered an important factor driving climate cooling (e.g. Haigh, 1996; Shindell et al., 1999; Bond et al., 2001; Mauquoy et al., 2002). The Wolf sunspot minimum coincides with the onset of the Little Ice Age (Mauquoy et al., 2002), an abrupt icecap growth in the Arctic Canada between 1275 and 1300 AD (Miller et al., 2012) and an increase in drift ice off Iceland in the late 13th century, which may have caused the failure of Viking settlement on Greenland (Andrews et al., 2009). The climax of the Little Ice Age at ca. 1675/80-1710 AD (Flohn, 1985; Lamb, 1983) is often associated with the Maunder minimum (Eddy, 1976). Adercotryma glomerata, in turn, is an epifaunal agglutinated species, which is often reported as occurring at $<4{ }^{\circ} \mathrm{C}$ and tolerating a wide salinity range (28-35) in the Northern Europe, Labrador Sea, Canadian Arctic, Antarctic (Schafer and Cole, 1982, 1986; Williamson et al., 1984; Alve, 1991; Kuhnt et al., 2000). This is also supported by a distinct increase of $A$. glomerara during the Dark Ages (after $\sim 400 \mathrm{AD}$ ) in our record (Polovodova et al., 2011). At the same time A. glomerata was mentioned as one of the dominant faunal components of the Medieval Warm Period (Polovodova et al., 2011), but it occurred during the MWP in lower concentrations (up to 30 ind. $\mathrm{g}^{-1}$ ) as compared with the LIA (up to 70 ind. $\mathrm{g}^{-1}$ ). Therefore, the increase of A. glomerata suggests that the intermediate Skagerrak water flowing into the fjord during the LIA could 
have been colder than today. This supports the general idea of climate cooling during ca. 1675-1700 AD, similar to the onset of the LIA when increase of $A$. glomerata coincides with the Wolf minimum.

In general the period of $1600-1850 \mathrm{AD}$ is characterised by an increased abundance of agglutinated species - A. glomerata, T. earlandi and E. scaber (Fig. 5). Wollenburg and Kuhnt (2000) report A. glomerata to prevail in low-energy environments characterised by lower carbon fluxes in the Arctic Ocean. This is consistent with our results, showing proliferation of A. glomerata during ca. 1600-1800 AD, which was characterised by a finer sediment interval, i.e. a lower amount of the sand-sized fraction (Figs. 4-5). Textularia earlandi, an omnivorous opportunist (Alve, 2010), is reported as a dominant faunal element in Canadian fjords at water depths $\geq 100 \mathrm{~m}$ (Schafer and Cole, 1988). Eggerelloides scaber is presented by Murray (2006) as a detritivorous shelf species, which demands salinity $>24$ for most of the year and temperatures $1-20^{\circ} \mathrm{C}$. Therefore, proliferation of these agglutinated species might imply a change in a quality of organic matter in Gullmar Fjord sediments during ca. 1600-1800 AD

Some studies pinpointed that an increase in arenaceous species may result from the dissolution of calcareous tests due to low temperatures (e.g. Murray and Alve, 1999; Steinsund and Hald, 1994). In our record, however, the degree of carbonate dissolution has been previously estimated as moderate (Polovodova et al., 2011), since together with agglutinated species we still find well preserved and shiny tests of thin-shelled species like $N$. iridea and S. fusiformis.

\subsubsection{Hyalinea balthica: a proxy of climate warming or changed diet composition?}

In general, based on the distribution of the main foraminiferal units, it appears that $1650 \mathrm{AD}$ is a starting point for the establishment of new foraminiferal faunas in the fjord. This is a time when $H$. balthica, typical of the area during the 20th century, increases in Gullmar Fjord (Figs. 4-5). It is a Boreal-Lusitanian species (Nørvang, 1945), which is present in higher latitudes and becomes less abundant at lower latitudes (Murray, 1971, 1973, 2006; Ross, 1984). Hass (1997) suggests that the assemblages of H. balthica in the Skagerrak are indicative of "stagnant conditions", which we interpret as less intense bottom water currents on the southern flank of the basin. Indeed, in one of his cores (15 535-1), there was an increase in $\mathrm{H}$. balthica during the calm and the coldest phase of the LIA (ca. 1550-1750 AD). Erbs-Hansen et al. (2011) also report that $H$. balthica increases during the LIA maximum. Our results are consistent with both studies and show $H$. balthica peaks at $\sim 1650 \mathrm{AD}$, then again at $\sim 1800 \mathrm{AD}$ and finally at $\sim 1900 \mathrm{AD}$. After that, H. balthica remains as a dominant species for about $80 \mathrm{yr}$, which is in contrast with most of the Hass' cores (except I KAL) displaying a general decrease of $H$. balthica after the LIA (Hass, 1997).
It is interesting that after occurring during the coldest phase of the LIA, the abundance of $H$. balthica peaks during the warming of the 1930s in our record (Polovodova et al., 2011). The immigration of $H$. balthica into the Skagerrak is also suggested to happen due to a climate warming (Nagy and Qvale, 1985: ca. 7800 BP) and this species occurs frequently in Eemian interglacial deposits of the North Sea (Feyling-Hanssen, 1980).

On the other hand, the first increase of the H. balthica unit after ca. $1650 \mathrm{AD}$ (see F4: Fig. 4) coincided with the offset in $\mathrm{C} / \mathrm{N}$ ratio values. After $1650 \mathrm{AD}, \mathrm{C} / \mathrm{N}$ values became lower than their long-term average, unlike the values present prior to this date. This could imply changes in the quality of organic matter, perhaps due to a decrease in primary productivity, which would most certainly have an effect on the species composition. Hyalinea balthica occurs in areas with relatively low quality (partially degraded) organic matter, mainly of terrestrial origin (Hess et al., 2005). According to Sweetman et al. (2009), the large-sized foraminifera (as H. balthica) usually display a slower response to fresh phytodetritus deposition compared to small and thin-shelled foraminiferal species (as e.g. $N$. iridea). Given that at $1650 \mathrm{AD} H$. balthica replaces $N$. iridea, a well-known fresh-phytodetritus-feeder (e.g. Gooday and Hughes, 2002; Duchemin et al., 2007; Alve, 2010; Goineau, 2012), the faunal shift may reflect reduced primary productivity and consequently the dominance of partially degraded organic matter at the sea floor. This is further supported by a small decrease in dinoflagellate cyst abundance (Nordberg and Harland, unpublished data) and $\delta^{13} \mathrm{C}$ values (Fig. 4). However, the simultaneous short decreases of both proxies at $1650 \mathrm{AD}$ are too small to draw any firm conclusions.

\subsection{Land use changes during the LIA}

From the $\mathrm{C} / \mathrm{N}$ data (Fig. 4) it is rather difficult to distinguish the sources of organic matter (marine vs. terrigenous) since the ratio fluctuates within the marine range. It has also been suggested that the $\mathrm{C} / \mathrm{N}$ ratio reflects organic matter sources inaccurately, since nitrogen is affected by organic matter diagenesis and biological controls (Thornton and McManus, 1994). Therefore, it may be hard to distinguish a marine versus a terrigenous source when using the $\mathrm{C} / \mathrm{N}$ ratio of degraded organic matter.

Filipsson and Nordberg (2010) studied $\delta^{13} \mathrm{C}$ of the tests from C. laevigata from core 9004 and suggested that changes in land use of the areas surrounding fjords may have occurred during the LIA. The intensification of land use through cultivation and deforestation would increase erosion of soils, which in Sweden generally have a high erosion risk due to presence of silt and marine clays (Ulén and Jakobsson, 2005). Soil erosion could lead to increased sediment transport by local streams and land runoff, as well as increased input of terrestrial organic matter into the fjord. The terrestrial carbon would shift $\delta^{13} \mathrm{C}$ towards lighter values, which does 
not occur around $1350 \mathrm{AD}$ (Fig. 4), but rather around 1500 AD. Based on the pollen data from the Gullmar Fjord, Fries (1951) showed an increase in non-arboreal pollen (NAP), which began at the end of the Medieval Warm Period and lasted until ca. $1650 \mathrm{AD}$ (Fig. 4). This suggests an intense clearing of forests to increase croplands and pasture together with exploitation of timber for construction. However, land use in Sweden and particularly Bohuslän most likely experienced a decline due to the outbreak of the Black Death around $1350 \mathrm{AD}$, which decreased the population by half or 2/3 (Harrison, 2000) and resulted in large scale abandonment of farms together with a series of wars, which followed thereafter (Fig. 4). The same was suggested for the records from the central Europe (Büntgen et al., 2011).

From ca. 1500 to $1850 \mathrm{AD}$, the $\delta^{13} \mathrm{C}$ values in our record become lighter. According to terrestrial records, changes in land use and irrigation during 1500-1700 AD increased losses of topsoil and finer particles in Sweden (Dearing et al., 1990) and led to a widespread deforestation in Scandinavian countries (Bradshaw et al., 2005; Kaplan et al., 2009). In addition, there were several productive herring periods in the Bohuslän and Norwegian fisheries (Cushing, 1982; Corten, 1999) after ca. $1550 \mathrm{AD}$. One of them, the so-called "Great Herring Period" (Den Stora Sillperioden: 1748-1808 AD) resulted in the extensive production of fish oil, which required a lot of wood for the boiling of herring guts and therefore lead to a substantial alteration of the landscape (Utterström, 1959; Byron, 1994).

\section{Conclusions}

The Little Ice Age period is clearly seen in the benthic foraminiferal records from the deep basin of Gullmar Fjord. Our results are in agreement with previous studies based on benthic foraminiferal stratigraphy from the Skagerrak region. The onset of the LIA is indicated by an increase in cold-water species Adercotryma glomerata. The first phase of the LIA has been characterised by a stormy climate and higher primary productivity, which is indicated by the foraminiferal unit of Nonionella iridea and Cassidulina laevigata. It is suggested that maximum abundances of $N$. iridea mirror a short and abrupt warming episode at $\sim 1600 \mathrm{AD}$. It is likely that due to deforestation, extensive fishing and land use changes in the second part of the LIA, there was an increased input of terrestrial organic matter to the Gullmar Fjord, which is indicated by lighter $\delta^{13} \mathrm{C}$ values and an increase of detritivorous and omnivorous foraminiferal species, such as Textularia earlandi and Eggerelloides scaber. At the same time, general climate deterioration during the climax of the LIA (1675-1704 AD), as suggested by the increase of agglutinated species, presence of Hyalinea balthica, and a decline of $N$. iridea, may have driven the decline in primary productivity during this period.
Acknowledgements. The authors thank the crews of R/V Svanic, R/V Skagerak, and personally Lennart Bornmalm and Ardo Robijn (University of Gothenburg) for help with sampling. Ardo Robijn also helped with picking of $C$. laevigata for isotope analysis; Monika Segl (University of Bremen, Germany) ran the stable isotope measurements; Asli Oflaz and Sofia Andersson did some foraminiferal analysis, and Tim Gallagher (University of Michigan, USA) scrutinized the English of the text. The manuscript has benefitted from the valuable comments and suggestions by Elisabeth Alve (University of Oslo, Norway) and Christian Hass (Alfred Wegener Institute, Germany). The research has been supported by University of Gothenburg (a postdoctoral fellowship to IPA), the Lamm Foundation and the Swedish Research Council (VR) (grants 621-2007-4369 to KN and 621-2005-4265 \& 621-2011-5090 to HLF). The full datasets discussed in this manuscript will be available online through the PANGAEA database.

Edited by: H. Kitazato

\section{References}

Alve, E.: Foraminifera, climatic change and pollution: A study of Late Holocene sediments in Drammensfjord, SE Norway, The Holocene 1, 243-261, 1991.

Alve, E.: Benthic foraminiferal responses to absence of fresh phytodetritus: a two-year experiment, Marine Micropalentol., 76, 67-75, 2010.

Alve, E. and Murray, J. W.: Benthic foraminiferal distribution and abundance changes in Skagerrak surface sediments: 1937 (Hoglund) and 1992/1993 data compared, Mar. Micropaleontol., 25, 26-288, doi:10.1016/0377-8398(95)00026-7, 1995.

Andrews, S. T., Belt, S., Olafsdottir, S., Massé, G., and Vare, L. L.: Sea ice and marine climate variability for NW Iceland/Denmark Strait over the last 2000 cal.yr. BP, The Holocene, 19, 775-784, 2009.

Arneborg, L.: Turnover times for the water above sill level in Gullmar Fjord, Cont. Shelf Res., 24, 443-460, 2004.

Arneborg, L., Erlandsson, C. P., Liljebladh, B., and Stigebrandt, A.: The rate of inflow and mixing during deep-water renewal in a sill fjord, Limnol. Oceanogr., 49, 768-777, 2004.

Belgrano, A., Lindahl, O., and Hernroth, B.: North Atlantic Oscillation primary productivity and toxic phytoplankton in the Gullmar Fjord, Sweden (1985-1996), P. Roy. Soc. B-Biol. Sci., 266, 425430, 1999.

Bianchi, G. G. and McCave, I. N.: Holocene periodicity in North Atlantic climate and deep-ocean flow south of Iceland, Nature, 397, 515-517, 1999.

Björck, S. and Clemmensen, L.: Aeolian sediment in raised bog deposits, Halland, SW Sweden: a new proxy record of Holocene winter storminess variation in southern Scandinavia?, The Holocene, 14, 677-688, 2004.

Björk, J. and Nordberg, K.: Upwelling along the Swedish west coast during the 20th century, Cont. Shelf Res., 23, 1143-1159, 2003.

Bond, G., Kromer, B., Beer, J., Muscheler, R., Evans, M. N., Showers, W., Hoffmann, S., Lotti-Bond, R., Hajdas, I., and Bonani, G.: Persistent solar influence on north Atlantic climate during the Holocene, Science, 294, 2130-2136, 2001.

Bradshaw, E. G., Rasmussen, P., and Odgaard, B. V.: Mid- to lateHolocene land-use change and lake development at Dallund $\mathrm{S} \emptyset$, 
Denmark: synthesis of multiproxy data, linking land and lake, The Holocene, 15, 1152-1162, 2005.

Bronk Ramsey, C.: Improving the resolution of radiocarbon dating by statistical analysis, in: Radiocarbon Dating: Archaeology, Text and Science, edited by: Levy, T. E. and Higham, T. F. G., The Bible and Equinox, London, 57-64, 2005.

Brückner, S. and Mackensen, A.: Deep-water renewal in the Skagerrak during the last 1200 years triggered by the North Atlantic Oscillation: evidence from benthic foraminiferal $\delta^{18} \mathrm{O}$, The Holocene, 16, 331-340, 2006.

Byron R.: The maritime household in Northern Europe, Comp. Stud. Soc. Hist., 36, 271-292, 1994.

Büntgen, U., Tegel, W., Nicolussi, K., McCormick, M., Frank, D., Trouet, V., Kaplan, J. O., Herzig, F., Heussner, K. U., Wanner, H., Luterbacher, J., and Esper, J.: 2500 Years of European Climate Variability and Human Susceptibility, Science, 331, 578582, 2011.

Cage, A. G. and Austin, W. E. N.: Marine climate variability during the last millennium: the Loch Sunart record, Scotland, UK, Quaternary Sci. Rev., 29, 1633-1647, 2010.

Clarke, M. L. and Rendell, H. M.: The impact of North Atlantic storminess on western European coasts: a review, Quatern. Int., 195, 31-41, 2009.

Clemmensen, L., Murray, A., Heinemeier, J., and De Jong, R.: The evolution of Holocene coastal dune fields, Jutland, Denmark: A record of climate change over the past 5000 years, Geomorphology, 105, 303-313, 2009.

Corten, A.: A proposed mechanism for the Bohuslän herring periods, ICES J. Mar. Sci., 56, 207-220, 1999.

Cushing, D. H.: Climate and fisheries, Academic Press, London, 1982.

Dearing, J. A., Alström, K., Bergman, A., Regnell, J., and Sandgreen, P.: Recent and long-term records of soil erosion from southern Sweden, in: Soil erosion on agricultural land, edited by: Boardman, J., Foster, I. D. L., and Dearing, J. A., Proceedings of a workshop sponsored by the British Geomorphological Research Group, Coventry, UK, 1990.

de Jong, R., Schoning, K., and Björck, S.: Increased aeolian activity during humidity shifts as recorded in a raised bog in southwest Sweden during the past 1700 years, Clim. Past, 3, 411-422, doi:10.5194/cp-3-411-2007, 2007.

de Jong, R., Hammarlund, D., and Nesje, A.: Late Holocene effective precipitation variations in the maritime regions of SouthWest Scandinavia. Quaternary Sci. Rev., 28, 54-64, 2009.

Duchemin, G., Fontanier, C., Jorissen, F. J., Barras, C., and Griveaud, C.: Living small-sized $(63-150 \mu \mathrm{m})$ foraminifera from mid-shelf to mid-slope environments in the Bay of Biscay, J. Foramin. Res., 37, 12-32, 2007.

Eddy, J. A.: The Maunder Minimum, Science, 192, 1189-1202, 1976.

Erbs-Hansen, D. R., Knudsen, K. L., Gary, A. C., Gyllencreutz, R., and Jansen, E.: Holocene climatic development in Skagerrak, eastern North Atlantic: foraminiferal and stable isotope evidence, The Holocene, 22, 301-312, 2011.

Erlandsson, C. P., Stigebrandt, A., and Arneborg, L.: The sensitivity of minimum oxygen concentrations in a fjord to changes in biotic and abiotic external forcing, Limnol. Oceanogr., 51, 631-638, 2006.
Feyling-Hanssen, R. W.: Foraminiferal indication of Eemian interglacial in the northern North Sea, Bulletin of Geological Society of Denmark, 29, 175-189, 1980.

Filipsson, H. L. and Nordberg, K.: Climate variations, an overlooked factor influencing the recent marine environment. An example from Gullmar Fjord, Sweden, illustrated by benthic foraminifera and hydrographic data, Estuaries, 27, 867-881, $2004 a$.

Filipsson, H. L. and Nordberg, K: A 200-year environmental record of a low-oxygen fjord, Sweden, elucidated by benthic foraminifera, sediment characteristics and hydrographic data, J. Foramin. Res., 34, 277-293, 2004b

Filipsson, H. L. and Nordberg, K: Variations in organic carbon flux and stagnation periods during the last 2400 years in a Skagerrak fjord basin, inferred from benthic foraminiferal $\delta^{13} \mathrm{C}$, in: Fjords: Depositional Systems and Archives, Geological Society Special Publication, edited by: Howe, J. A., Austin, W. E. N., Forwick, M., Powell, R. D., and Paetzel, M., 261-270, 2010.

Filipsson, H. L., Nordberg, K., and Gustafsson, M.: Seasonal study of $\delta^{18} \mathrm{O}$ and $\delta^{13} \mathrm{C}$ in living (stained) benthic foraminifera from two Swedish fjords, Mar. Micropaleontol., 53, 159-172, 2004.

Flohn, H.: Das Problem der Klimaveränderungen in Vergangenheit und Zukunft/The problem of past and future climate change, Wiss. Buchges., Darmstadt, 220 pp., 1985 (in German).

Fricke, H. C., Oneil, J. R., and Lynnerup, N.: Oxygen-Isotope Composition of Human Tooth Enamel from Medieval Greenland Linking Climate and Society, Geology, 23, 869-872, 1995.

Fries, M.: Pollenanalytiska vittnesbörd om senkvartär vegetationsutvekling, särskilt skoghistoria, i nord-västra Götaland/ Pollenanalytical evidence about late Quaternary development of vegetation and particularly forests in the north-western Götaland, Acta Phytogeographica Suecia, 29, 220 pp., 1951 (in Swedish).

Godhe, A. and McQuoid, M. R.: Influence of benthic and pelagic environmental factors on the distribution of dinoflagellate cysts in surface sediments along the Swedish west coast, Aquat. Microb. Ecol., 32, 185-201, 2003.

Godhe, A., Noren, F., Kuylenstierna, M., Ekberg, C., and Karlson, B.: Relationship between planktonic dinoflagellate abundance, cysts recovered in sediment traps and environmental factors in the Gullmar Fjord, Sweden, J. Plankton Res., 23, 923-938, 2001.

Goineau, A., Fontanier, C., Jorissen, F., Buscail, R., Kerhervé, P., Cathalot, C., Pruski, A. M., Lantoine, F., Bourgeois, S., Metzger, E., Legrand, E., and Rabouille, C.: Temporal variability of live (stained) benthic foraminiferal faunas in a river-dominated shelf - Faunal response to rapid changes of the river influence (Rhône prodelta, NW Mediterranean), Biogeosciences, 9, 13671388, doi:10.5194/bg-9-1367-2012, 2012.

Gooday, A. J. and Hughes, J. A.: Foraminifera associated with phytodetritus deposits at a bathyal site in the northern Rockall Trough (NE Atlantic): seasonal contrasts and a comparison of stained and dead assemblages, Mar. Micropaleontol., 46, 83110, 2002.

Grove, J. M.: The initiation of the "Little Ice Age" in regions round the North Atlantic, Climatic Change, 48, 53-82, 2001.

Gunnarson, B. E., Linderholm, H. W., and Moberg, A.: Improving a tree-ring reconstruction from west-central Scandinavia: 900 years of warm-season temperatures, Clim. Dynam., 36, 97-108, 2011. 
Gustafsson, M. and Nordberg, K.: Living (stained) benthic foraminiferal response to primary production and hydrography in the deepest part of the Gullmar Fjord, Swedish West Coast, with comparisons to Hoglund's 1927 material, J. Foramin. Res., 31, 2-11, 2001.

Haigh, J. D.: The impact of solar variability on climate, Science, 272, 981-984, 1996.

Halpern, B. S., Walbridge, S., Selkoe, K. A., Kappel, C. V., Micheli, F., D’Agrosa, C., Bruno, J. F., Casey, K.,S., Ebert, C., Fox, H. E., Fujita, R., Heinemann, D., Lenihan, H.S., Madin, E. M. P., Perry, M. T., Selig, E. R., Spalding, M., Steneck, R., and Watson, R.: A global map of human impact on marine ecosystems, Science, 319, 948-952, 2008.

Hammer, Ø., Harper, D. A. T., and Ryan, P. D.: PAST: Paleontological Statistics Software Package for Education and Data Analysis, Palaeontologica Electronica, 4, 1-9, 2001.

Harland, R., Nordberg, K., and Filipsson, H. L.: Dinoflagellate cysts and hydrographical change in Gullmar Fjord, west coast of Sweden, Sci. Total Environ., 355, 204-231, 2006.

Harrison, D.: Stora Döden/ The Black Death, Stockholm, Ordfront, 2000 (in Swedish).

Hass, H. C.: Northern Europe climate variations during late Holocene: evidence from marine Skagerrak, Palaeogeogr. Palaeocl., 123, 121-145, 1996.

Hass, H. C.: The benthic foraminiferal response to late Holocene climate change over northern Europe, in: Contributions to the micropaleontology and paleoceanography of the Northern North Atlantic, edited by: Hass, H. C. and Kaminski, M. A., Grzybowski Foundation Special Publication, 5, 199-216, 1997.

Hass, C., Kuhn, G., Monien, P., Brumsack, H.-J., and Forwick, M.: Climate fluctuations during the past two millennia as recorded in sediments from Maxwell Bay, South Shetland Islands, West Antarctica, in: Fjords: Depositional Systems and Archives, edited by: Howe, J. A., Austin, W. E. N., Forwick, M., and Paetzel, M., Geological Society Special Publication, 243-260, 2010.

Hess, S., Jorissen, F. J., Venet, V., and Abu-Zied, R.: Benthic foraminiferal recovery after recent turbidite deposition in Cap Breton canyon, Bay of Biscay, J. Foramin. Res., 35, 114-129, 2005.

Howe, J. A., Austin, W. E. N., Forwick, W., Paetzel, M., Harland, R., and Cage, A. G.: Fjord systems and archives: a review, in: Fjords: Depositional Systems and Archives, edited by: Howe, J. A., Austin, W. E. N., Forwick, M., and Paetzel, M., Geological Society Special Publication, 261-270, 2010.

Hughes, M. K. and Diaz, H. F.: Was there a Medieval Warm Period, and if so, where and when?, Climatic Change, 26, 109-142, 1994.

Hughes, J. A., Gooday, A. J., and Murray, J. W.: Distribution of live benthic foraminifera at three oceanographically dissimilar sites in the northeast Atlantic: preliminary results, Hydrobiologia, 440, 227-238, 2000.

Inall., M. E. and Gillibrand, P. A.: The physics of mid-latitude fjords: a review, in: Fjords: Depositional Systems and Archives, edited by: Howe, J. A., Austin, W. E. N., Forwick, M., and Paetzel, M., Geological Society Special Publication, 17-33, 2010.

Kaplan, J. O., Krumhardt, K. M., and Zimmermann, N.: The prehistoric and preindustrial deforestation of Europe, Quaternary Sci. Rev., 28, 3016-3034, 2009.
Klovan, J. E. and Imbrie, J.: An algorithm and FORTRAN-IV program for large scale Q-mode factor analysis and calculation of factor scores, Math. Geol., 3, 61-77, 1971.

Kuhnt, W., Collins, E., and Scott, D. B.: Deep water agglutinated foraminiferal assemblages across the Gulf Stream: distribution patterns and taphonomy, in: Proceedings of the Fifth International Workshop on Agglutinated Foraminifera, edited by: Hart, M. B., Kaminski, M. A., and Smart, C. W., Gryzbowski Foundation Special Publication, 7, 261-298, 2000.

Lamb, H. H.: Some studies of the Little Ice Age of recent centuries and its great storms, in: Climatic changes on a yearly to millennial basis: Geological, historical and instrumental records, edited by: Mörner, N. A. and Karlén, W., D. Reidel Publishing Company, Dordrecht, 1983.

Leijonhufvud, L., Wilson, R., Moberg, A., Soderberg, J., Retso, D., and Soderlind, U.: Five centuries of Stockholm winter/spring temperatures reconstructed from documentary evidence and instrumental observations, Climatic Change, 101, 109-141, 2010.

Lindahl, O., Belgrano, A., Davidsson, L., and Hernroth, B.: Primary production, climatic oscillations, and physico-chemical processes: the Gullmar Fjord time-series data set (1985-1996), ICES J. Mar. Sci., 55, 723-729, 1998.

Lindahl, O. and Hernroth, L.: Phyto-Zooplankton Community in Coastal Waters of Western Sweden - an Ecosystem Off Balance, Mar. Ecol.-Prog. Ser., 10, 119-126, 1983.

Ljungqvist, F. C.: Temperature Proxy Records Covering the Last Two Millennia: A Tabular and Visual Overview, Geograf. Ann. A, 91, 11-29, 2009.

Ljungqvist, F. C.: A regional approach to the Medieval Warm Period and the Little Ice Age, in: Climate change and variability, edited by: Simard, S. W. and Austin, M. E., Sciyo, p. 486, 2010.

Ljungman, A.: The Bohuslän sea fisheries and their future, Report of the commissioner for 1980, US Commission Fish Fisheries, 89-98, 1883.

Lund, D. C., Lynch-Stieglitz, J., and Curry, W. B.: Gulf Stream density structure and transport during the past millennium, Nature, 444, 601-604, 2006.

Mauquoy, D., van Geel, B., Blaauw, M., and van der Plicht, J.: Evidence from northwest European bogs shows "Little Ice Age" climatic changes driven by variations in solar activity, The Holocene, 12, 1-6, 2002.

McDermott, F., Mattey, D. P., and Hawkesworth, C.: Centennialscale Holocene climate variability revealed by a high-resolution speleothem delta O-18 record from SW Ireland, Science, 294, 1328-1331, 2001.

Mendes, I., Gonzalez, R., Dias, J. M. A., Lobo, F., and Martins, V. Factors influencing recent benthic foraminifera distribution on the Guadiana shelf (Southwestern Iberia), Mar. Micropaleontol., 51, 171-192, 2004.

Miller, G. H., Geirsdottir, A., Zhong, Y. F., Larsen, D. J., OttoBliesner, B. L., Holland, M. M., Bailey, D. A., Refsnider, K. A., Lehman, S. J., Southon, J. R., Anderson, C., Bjornsson, H., and Thordarson, T.: Abrupt onset of the Little Ice Age triggered by volcanism and sustained by sea-ice/ocean feedbacks, Geophys. Res. Lett., 39, L02708, doi:10.1029/2011GL050168, 2012.

Moberg, A., Sonechkin, D. M., Holmgren, K., Datsenko, N. M., and Karlén, W.: Highly variable Northern Hemisphere temperatures reconstructed from low- and high-resolution proxy data, Nature, 433, 613-617, 2005. 
Murray, J. W.: An atlas of British Recent Foraminiferids. American Elsevier Publishing Co., Inc., New York, 1971.

Murray, J. W.: Distribution and Ecology of Living Benthic Foraminiferids. Crane, Russak and Co., Inc., New York, 1973.

Murray, J. W.: An illustrated guide to the benthic foraminifera of the Hebridean shelf, west of Scotland, with notes on their mode of life, Palaeontologia Electronica, 5, 1-31, 2003.

Murray, J. W.: Ecology and Applications of Benthic Foraminifera, Cambridge University Press, Cambridge, 2006.

Murray, J. W. and Alve, E.: Taphonomic experiments on marginal marine foraminiferal assemblages: how much ecological information is preserved?, Palaeogeogr. Palaeocl., 149, 183-197, 1999.

Nagy, J. and Qvale, G.: Benthic foraminifers in upper Quaternary Skagerrak deposits, Norsk Geologisk Tidsskrift, 65, 107-113, 1985.

Nordberg, K., Filipsson, H. L., Linne, P., and Gustafsson, M.: Stable oxygen and carbon isotope information on the establishment of a new, opportunistic foraminiferal fauna in a Swedish Skagerrak fjord basin, in 1979/1980, Mar. Micropaleontol., 73, 117-128, 2009.

Nordberg, K., Gustafsson, M., and Krantz, A. L.: Decreasing oxygen concentrations in the Gullmar Fjord, Sweden, as confirmed by benthic foraminifera, and the possible association with NAO, J. Marine Syst., 23, 303-316, 2000.

Nordli, P. O.: Reconstruction of nineteenth century summer temperatures in Norway by proxy data from farmers' diaries, Climatic Change, 48, 201-218, 2001.

Nørvang, A: The zoology of Iceland, Foraminifera, 2, 1-79, Munksgaard, Copenhagen and Reykjavik, 1945.

Polovodova, I., Nordberg, K., and Filipsson, H. L.: The benthic foraminiferal record of the Medieval Warm Period and the Recent Warming in the Gullmar Fjord, Swedish west coast, Mar. Micropaleontol., 81, 95-106, 2011.

Porter, S. C.: Pattern and forcing of Northern-Hemisphere glacier variations during the last millenium, Quaternary Res., 26, 27-48, 1986.

Qvale, G., Markussen, B., and Thiede, J.: Benthic Foraminifers in Fjords - Response to Water Masses, Norsk Geologisk Tidsskrift, 64, 236-249, 1984.

Redfield, A. C., Ketchum, B. H., and Richards, F. A.: The influence of organisms on the composition of seawater, in: The Sea, Wiley, edited by: Hill, M. N., New York, 26-77, 1963.

Reimer, P. J., Baillie, M. G. L., Bard, E., Bayliss, A., Beck, J. W., Bertrand, C. J. H., Blackwell, P. G., Buck, C. E., Burr, G. S., Cutler, K. B., Damon, P. E., Edwards, R. L., Fairbanks, R. G., Friedrich, M., Guilderson, T. P., Hogg, A. G., Hughen, K. A., Kromer, B., McCormac, G., Manning, S., Ramsey, C. Bronk, Reimer, R. W., Remmele, S., Southon, J. R., Stuiver, M., Talamo, S., Taylor, F. W., van der Plicht, J., and Weyhenmeyer, C. E.: IntCal04 terrestrial radiocarbon age calibration, 0-26 cal kyr BP, Radiocarbon, 46, 1029-1058, 2004.

Risgaard-Petersen, N., Langezaal, A. M., Ingvardsen, S., Schmid, M. C., Jetten, M. S. M., Op den Camp, H. J. M., Derksen, J. W. M., Pina-Ochoa, E., Eriksson, S. P., Nielsen, L. P., Revsbech, N. P., Cedhagen, T., and van der Zwaan, G. J.,: Evidence for complete denitrification in a benthic foraminifer, Nature, 443, 93-96, 2006.
Ross, C. R.: Hyalinea balthica and its late Quaternary paleoclimatic implications; Strait of Sicily, J. Foramin. Res., 14, 134139, 1984.

Rydberg, L.: Circulation in the Gullmaren - a silll fjord with externally maintained stratification. Inst. of Oceanography, Univ. of Gothenburg, Report no: 23 (mimeo), Gothenburg, 1977.

Schafer, C. T. and Cole, F. E.: Living benthic foraminifera distributions on the continental slope and rise east of Newfoundland, Canada, Geol. Soc. Am. Bull., 93, 207-217, 1982.

Schafer, C. T. and Cole, F. E.: Reconnaissance survey of benthonic foraminifera from Baffin Island fjord environments, Arctic 39, 232-239, 1986.

Schafer, C. T. and Cole, F. E.: Environmental associations of Baffin Island fjord agglutinated foraminifera, Abh. Geol. Bundesanst., 41, 307-323, 1988.

Schröder-Adams, C. J.: Middle Eocene to Holocene benthic foraminifer assemblages from the Kerguelen Plateau (Southern indian Ocean), Proceedings of the Ocean Drilling Program, Scientific Results, 611-630, 1991.

Schöllhorn, E. and Graneli, E.: Influence of different nitrogen to silica ratios and artificial mixing on the structure of a summer phytoplankton community from the Swedish west coast (Gullmar fjord), J. Sea Res., 35, 159-167, 1996.

Seidenkrantz, M. S.: Benthic foraminiferal and stable isotope evidence for "Younger Dryas-style" cold spell at the SaalianEemian transition, Denmark, Palaeogeogr. Palaeocl., 102, 103120, 1993.

Seidenkrantz, M. S. and Knudsen, K. L.: Marine High-Resolution Records of the Last Interglacial in Northwest Europe - a Review, Géographie Physique et Quaternaire, 48, 157-168, 1994.

Sicre, M. A., Hall, I. R., Mignot, J., Khodri, M., Ezat, U., Truong, M. X., Eiriksson, J., and Knudsen, K. L.: Sea surface temperature variability in the subpolar Atlantic over the last two millennia, Paleoceanography, 26, PA4218, 2011.

Shindell, D., Rind, D., Balachandran, N., Lean, J., and Lonergan, P.: Solar cycle variability, ozone, and climate, Science, 284, 305308, 1999.

Steinsund, P. I. and Hald, M.: Recent calcium carbonate dissolution in the Barents Sea: paleoceanographic applications, Mar. Geol., 117, 303-316, 1994.

SMHI: Swedish Meteorological and Hydrological Institute, Marine Environmental Data, available at: http://produkter.smhi.se/ pshark/datamap_bohuskusten.php?language=s, 2012.

Stuiver, M. and Pollach, H. A.: Discussions of reporting 14C data, Radiocarbon, 19, 355-363, 1977.

Sweetman, A. K., Sommer, S., Pfannkuche, O., and Witte, U.: Retarded response by macrofauna-size foraminifera to phytodetritus in a deep Norwegian fjord, J. Foramin. Res., 39, 15-22, 2009.

Thornton, S. F. and McManus, J.: Application of organic carbon and nitrogen stable isotope and $\mathrm{C} / \mathrm{N}$ ratios as source indicators of organic matter provenance in estuarine systems: evidence from the Tay Estuary, Scotland, Estuar. Coast. Shelf Sci., 38, 219-233, 1994.

Trouet, V., Esper, J., Graham, N. E., Baker, A., Scourse, J. D., and Frank, D. C.: Persistent Positive North Atlantic Oscillation Mode Dominated the Medieval Climate Anomaly, Science, 324, 78-80, 2009.

Ulén, B. and Jakobsson, C.: Critical evaluations of measures to mitigate phosphorus losses from agricultural land to surface waters 
in Sweden, Sci. Total Environ., 344, 37-50, 2005.

Utterström, G.: Migratory labor and the herring fisheries of Western Sweden in the 18th century, Scandinavian Economic History Review, 7, 3-40, 1959.

Wanner, H., Solomina, O., Grosjean, M., Ritz, S. P., and Jetel, M.: Structure and origin of Holocene cold events, Quaternary Sci. Rev., 30, 3109-3123, 2011.

Williamson, M. A., Keen, C. E., and Mudie, P. J.: Foraminiferal distribution on the continental margin off Nova Scotia, Mar. Micropaleontol., 9, 219-239, 1984.
Wollenburg, J. E. and Kuhnt, W.: The response of benthic foraminifers to carbon flux and primary production in the Arctic Ocean, Mar. Micropaleontol., 40, 189-231, 2000.

Xoplaki, E., Luterbacher, J., Paeth, H., Dietrich, D., Steiner, N., Grosjean, M., and Wanner, H.: European spring and autumn temperature variability and change of extremes over the last half millennium, Geophys. Res. Lett., 32, L15713, 2005. 